\title{
Early Italian Computing Machines and Their Inventors
}

\author{
Silvio Hénin \\ silvio.heninafastwebnet.it
}

\begin{abstract}
Nineteen centuries of Italian inventors and inventions in the field of aids to arithmetic and algebraic computing, before the electronic computer era, are reviewed; most of them forgotten or still unknown. Not meant to be a complete or ultimate treatise on the topic, this paper hopefully wants to be a starting point for more multidisciplinary research of Italian history of technology.
\end{abstract}

Keywords: mechanical calculating machines, history, Italy, $1^{\text {st }}-20^{\text {th }}$ century.

\section{Introduction}

Taking into account all kinds of arithmetical and mathematical instruments ever invented, since Sumerian arithmetic tablets (c. 2,500 BCE) and Chinese and Greek abacus $\left(5^{\text {th }}-4^{\text {th }}\right.$ Century BCE), tools to simplify the annoying calculation labor appeared rather soon in the history of civilization (Campbell-Kelly 2003 pp. 19-43; Needham 1959 pp. 29-63; Schärlig 2001, pp. 61-104). To be sure, multiplication tables and abaci were adequate for the limited calculation need of merchants and court bookkeepers until seventeenth century, when the Scientific Revolution and growing government bureaucracies asked for much more intricate and precise computing to be carried out, inducing the mathematician-philosopher Gottfried Leibniz to cry out "[...] it is beneath the dignity of excellent men to waste their time in calculation when any peasant could do the work just as accurately with the aid of a machine" and to invent one of the first mechanical calculators in 1672, the third one after Schickard's 'calculating clock' and Pascal's 'pascaline' .

In the following two centuries a number of scientists and artisans devoted themselves to design and build computing machinery, slowly transforming those contrivances from 'useless toys ... doomed to failure' (Williams 1990, p. 50) - though often aesthetically beautiful and of great ingenuity - to useful and reliable instruments, mass produced and sold in quantity. It was the coming of the industrial revolution and industrial capitalism in the United States, last decade of nineteenth century, which produced the 'crisis of control' (Beniger 1986), in turn creating a market for reliable, fast and error-free way to process large quantities of numerical and statistical data. In fact, despite the foregoing example in France by Thomas de Colmar, it was in the US that the data-processing industry began to bloom, in a few decades becoming a successful and highly profitable business (Williams 1997, pp. 145-151).

In the two centuries (c. 1650 - c. 1850) of 'incubation' mentioned above, more than one hundred prototypes of mechanical calculating machines have been proposed by an almost equal number of inventors, in all European countries. Particularly prolific in 
this field were France and the German-speaking countries ${ }^{1}$, followed at a distance by the United Kingdom (Campbell-Kelly 1989, pp. 6-7). In this panorama, only a score of Italian inventors and inventions are recorded and even fewer have been mentioned in international scholarly literature; thus it seems fair to revive their remembrance. Though modern Italy, as unified state/nation, is only one century and a half old (1861), what follows is an account of inventors and inventions belonging to the Italian cultural environment, regardless of coeval political situation.

\section{The Roman Pocket Abacus}

The abacus is the oldest and the longest lasting calculating device, possibly anticipating consistent number naming and writing (Menninger 1992, pp. 295-388); the independent invention of variously shaped abaci in different ancient cultures is evidence of both ingenuity and need. In the Etruscan and Roman culture 'table abaci' (akin to Greek Salami's table of 300 BCE) were largely diffused - due to the cumbersome, almost impossible, procedure to reckon with Roman numerals - and several Latin writers (e.g. Cicero, Martial, Juvenal and Pliny) mentioned the use of loose calculi (pebbles, beads), laid on wooden tablets to help computing (Schärlig 2006, pp. 70-71) . Pictures of table abaci are recorded on an Etruscan cameo, on a Roman pier found in Trier (Germany) and on a bas-relief of the Capitoline Museums in Rome (Schärlig 2006, pp. 72-74). Unfortunately, no relics of Roman wooden or marble counting tables have yet been found.

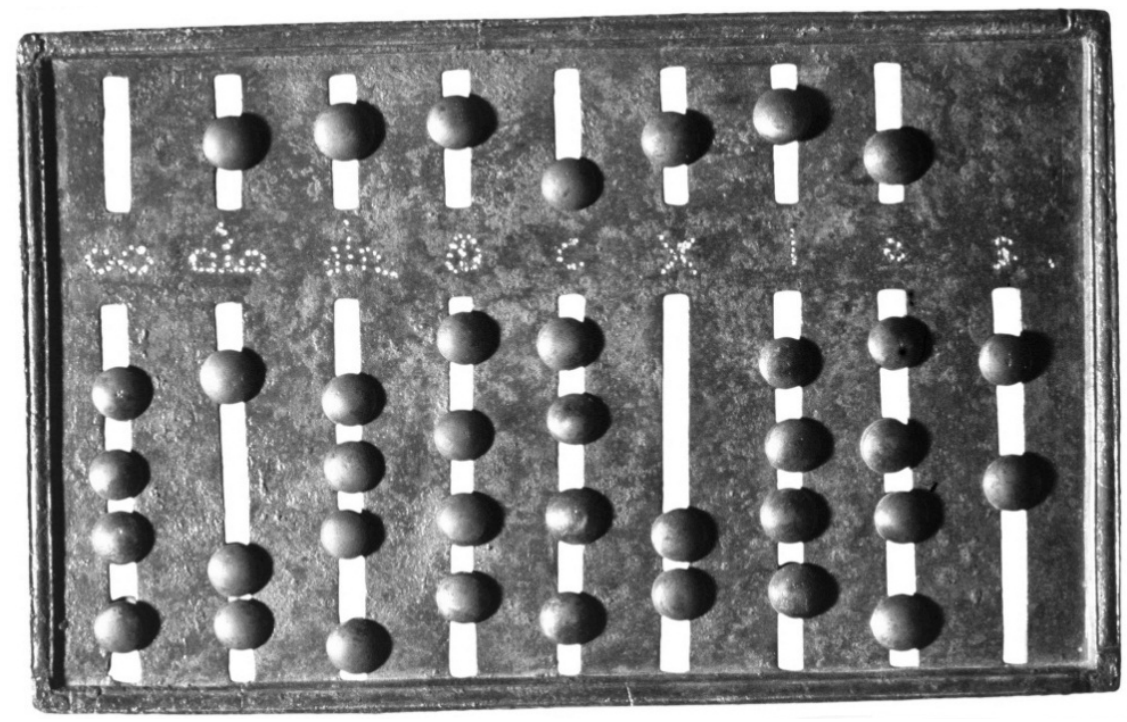

Fig. 1. Roman pocket abacus $\left(1^{\text {st }}\right.$ century CE) (Museo Nazionale Romano, Ministero per i Beni Culturali, Soprintendenza Speciale per i Beni Archeologici di Roma)

\footnotetext{
${ }^{1}$ Although a loose German League of 39 sovereign states was founded in 1814 (Deutscher Bund), Germany became a unified nation in 1871 .
} 
Specimens of a more interesting, perhaps unique, sort of Roman abacus, the 'portable' or 'pocket' abacus, came to light in $16^{\text {th }}-17^{\text {th }}$ century. Two of them have been thoroughly described (Welser 1594, pp. 241-243, Pignoria 1613, pp. 170-173) and a third, belonging to Ursinus ${ }^{2}$, just briefly mentioned (Smith 1925, p. 165). Nowadays three specimens only are known to still exist: one at the Museo Nazionale Romano in Rome, the second at the Bibliothéque National, Cabinet des medailles, in Paris, and the third at the Museo Archeologico Regionale in Aosta (Northern Italy) recently found in a burial ground (Martin 1989, Fellman 1983). Comparing Welser's and Pignoria's descriptions with the three extant relics, Renaissance's specimens are hardly the ones collected in the European museums nowadays ${ }^{3}$.

Roman pocket abaci have been dated around $1^{\text {st }}-2^{\text {nd }}$ century CE, possibly used for calculation with Roman coin 'as' and its fractions (1/12, uncia; 1/24, semuncia; 1/48, sicilico; 1/72, duella); their owners were probably local administrators or imperial travelling inspectors. Pocket abaci are little bronze tablet $(10 \times 7 \mathrm{~cm})$ with pairs of slots holding sliding beads - this arrangement prevents the counters to be lost, a solution to safely carry them around in pockets or bags. Each slot pair represents an order of magnitude $(1-10-100-\ldots)$ each with a lower 'units' slot (with four counters) and an upper 'fives' slot (with one counter); thus to represent the number 8 one has to move one 'fives' counter and three 'units' counters up. On the right side other three slots were used for $a s$ ' fractions, with one or two counters each. The strong similarity, in terms of architecture and mode of use, with old and modern Japanese soroban and Chinese suan-pan is impressive, but evidence of reciprocal influence can hardly be proved; though irregular and indirect contacts between China and the Roman Empire have been recorded (e.g. for silk trade) no evidence of direct cultural cross-influence has yet been found.

\section{The Renaissance: Analog Devices}

Since $13^{\text {th }}-14^{\text {th }}$ century, the study of mathematics, particularly algebra, began to flourish in Italy thanks to the discovery and the translation into Latin of ancient Greek and Hellenistic treatises and of Middle Age Islamic scholars. Mathematicians like Leonardo Pisano (aka Fibonacci), Luca Pacioli, Niccolò Tartaglia, Gerolamo Cardano, Raffaele Bombelli kept Italian mathematics well in advance of other European countries for the next two centuries. Also in applied mathematics Italian schools excelled; as George Ifrah recounts : "A wealthy German merchant seeking to provide his son with a good business education, consulted a learned man as to which European institution offered the best training. 'If you only want him to be able to cope with additions and subtractions, the expert replied, 'then any French or German University will do. But if you are intent on your son going on to multiplication or division, then you will have to send him to Italy" (Ifrah 2000, p. 577). Ancient technology was also

2 Possibly Fulvius Ursinus (1529-1600), antiquarian and philologist, librarian of Cardinal Farnese in Rome.

${ }^{3}$ Another alleged Roman abacus $\left(2^{\text {nd }}-5^{\text {th }}\right.$ century CE), in ivory, is reported in the European IBM Collection in Paris (http://www-sop.inria.fr/amisa/piece2Eng.html, Accessed January $12,2012)$, but all my attempts to gather more information from IBM remained unanswered. 
re-discovered (e.g. Hero of Alexandria's), design and construction of mathematical and astronomical instruments flourished and able instrument makers were prized at sovereigns' courts.

A number of practical instruments were invented to help sailors, gunners, architects and painters (Williams 1997, pp. 66-83; Favaro 1907). One instrument was particularly appreciated for ease of use and practical applications: the proportion compass or reduction compass, an analog device with two brass arms hinged together. Indexed scales were sometimes engraved, either on a separate rule or on the arms, to solve trigonometric and geometrical problems, thanks to the proportionality between homologous sides of triangles; in this case the instrument was better known as a 'sector'. Sectors helped calculations for navigation, survey and gunnery, until the engineers' slide rule replaced it (Williams 1997, pp. 75-83). The origin of the proportion compass can be traced back to Leonardo da Vinci (1452-1519) (Camerota 2000, pp. 14-15), afterwards a number of diverse types for different applications were proposed by several inventors all over Europe. The mathematician Niccolò Tartaglia (1499-1557) invented two gunner's sectors in 1560 for gun aiming and evaluation of target distance and height. Another more advanced Italian sector-like instrument is ascribable to Federico Commandino (1509-1575), mathematician known for the translation of several Greek treatises by Archimedes, Aristarchus of Samos, Euclid, Ptolemy and Hero of Alexandria. Commandino designed a 'polymetric compass' (c. 1568) (Bianca 1982) and one of his friends, the anatomist Bartolomeo Eustachi asked him to build one for his anatomical studies on the 'cartography' of human body (Andretta 2009, pp. 93-124) . One of Commandino's pupils was Marquis Guidobaldo Del Monte (1545 -1607) who studied at the University of Padua, was appointed supervisor of Grand Duchy of Tuscany's munitions and published several books on mathematics, astronomy, perspective and mechanics; he was also Galileo's friend and helped him to obtain the chair of mathematics at the University of Pisa. Del Monte built a sector (Drake 1988, pp 76-77) and a mechanical calculator that, by a gear train, converted any fraction of a degree into minutes and seconds (Gamba 1988, pp. 85-87, Camerota 2000, pp. 71-72). A previous inventor was Fabrizio Mordente (1532-1608) who at the age of twenty left Italy and travelled for ten years in North Africa, Middle East, India and most of Europe, where he paid visit to several scholars and instrument makers. Eventually he worked in the service of Emperor Maximillian II in Vienna, of Rudolph II in Prague and of Alessandro Farnese, Duke of Parma and Piacenza. In 1567 Mordente began to design a simple reduction compass to divide lines and arcs, perhaps influencing del Monte and Commandino, and improved it in the following decades with a better instrument of 1572 (compasso magistrale), an even better one in 1585 and an ultimate type in 1591 known as 'eightpoint compass' (Boffito 1931; Camerota 2000; Camerota 2003). The latter had four sliding and four fixed points and a detached rule with proportional scales. Italian philosopher Giordano Bruno prized Mordente's compass and published De Mordentii circino (On Mordente's sector, Paris, 1586) where he postulated Mordente's mathematical approach could help confute Aristotelian hypothesis of the incommensurability of infinitesimal quantities (Aquilecchia 1957, Camerota 2000, pp. 83-105]. 


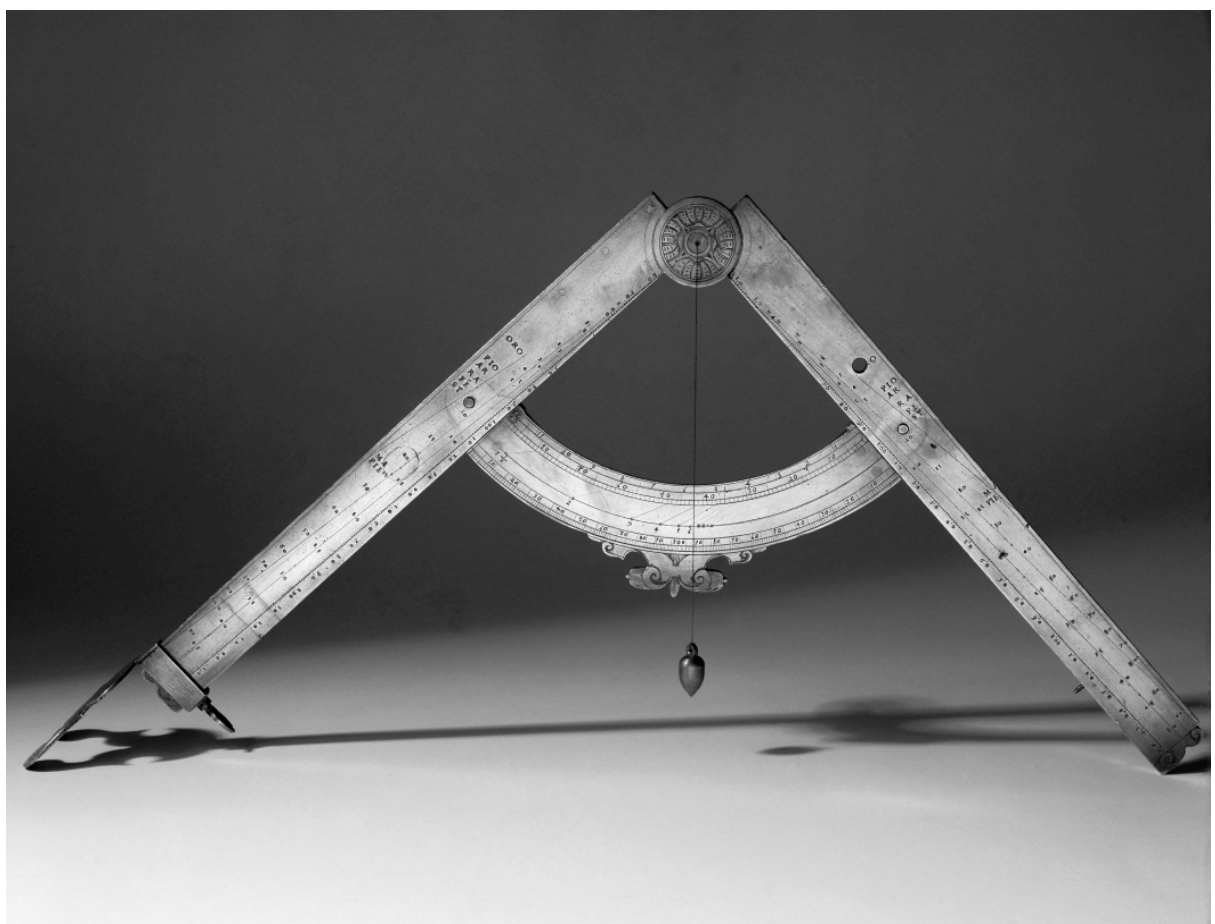

Fig. 2. Galileo Galilei's Compasso Geometrico-Militare (1597-1606) (Museo Galileo, Florence, - Photography Franca Principe)

Certainly the most known Italian sector is the one invented by Galileo Galilei (1564-1642) (Favaro 1907; Geymonat 1970, pp. 189-222; Vergara-Caffarelli 1992; Drake 1999, pp. 5-32) called 'compasso geometrico militare' (geometricmilitary compass). Galileo designed it in 1597, while professor of mathematics at the University of Padua, and began to build some with the help of Marcantonio Mazzoleni, able instrument maker, to teach his student practical applications of geometry. In the following years Galileo's compasso was modified transforming it from a 'Swiss knife' for practical use - like most other coeval sectors to a 'general purpose analog computer' for abstract quantities. More than 100 specimens have been built in the following ten years and 30 of them were presented to European sovereigns (Vergara-Caffarelli 2006), several others sold to Galileo's students. In 1606 Galileo published a 'user manual' for his compasso (Galilei 1606) in 60 copies - his first printed publication - to help using the contrivance. The success was impressive: soon the number of booklet and compassi available were insufficient to satisfy the request, though several instrument makers had started to produce copies, sometimes rough and useless (VergaraCaffarelli 2006). Already in 1607 Baldassarre Capra (c. 1580-1626) tried to claim credit for the invention of the instrument in his 'Usus et fabrica circini cuiusdam proportionis', but Galileo strenuously counteracted and Capra was censored by 
the Paduan University board. Galileo's invention assured him the return to the University of Pisa in 1610 and the protection of Grand Duke Cosimo II de' Medici.

Galileo's priority for the invention of the sector is still debated nowadays (Favaro 1883, p. 166; Drake 1999, p 7-12; Vergara-Caffarelli 1992). As we have seen, accounts of history of mathematics and technology mention several 16 th-17th century inventors of 'sectors' in Italy ${ }^{4}$ and in Europe ${ }^{5}$; multiple independent inventions are common in the history of technology (Merton 1973, pp. 343-70.). Indeed the idea was 'in the air' for a long time and many inventors followed it; moreover it is quite difficult to distinguish between marginal improvements and true innovations and to argue of possible plagiarism seems even harder, apart from Capra's gullible attempt. Thomas Hood's sector (1598) is possibly Galileo invention's nearest thing, but any reciprocal influence can be ruled out (Drake 1999, p. 7). Certainly Galileo's compasso was the first 'calculating sector' in use for a variety of problems, it shows several important and useful improvements over previous and contemporary models: a higher number of scales, a better precision and simplicity of use; nevertheless, as all its competitors, remained a low precision tool - due to the small size precision was two-figures at the best - more suited for education than for practical application, as Galileo himself stated in his writings (Vergara-Caffarelli 1992).

\section{$4 \quad 17^{\text {th }}-18^{\text {th }}$ Century: Early Mechanical Digital Calculators}

\subsection{The Mysterious N. 3179}

In the first half of $17^{\text {th }}$ Century mechanical digital calculators to execute the four arithmetic operations appeared in Europe, achievement made possible thanks to the advancement of clock technology ${ }^{6}$. No history of computing fails to mention Blaise Pascal's and Gottfried Wilhelm Leibniz's inventions, the pascaline (1645, for addition and subtraction) and the stepped reckoner (1673 for multiplication and division) respectively. A previous contrivance by Wilhelm Schickard, the rechenuhr (calculating clock) of 1623 is sometimes forgotten, but it cannot have influenced Pascal and Leibniz, having been lost in the Thirty Years War and re-discovered in 1935 (Williams 1997, pp. 118-45). In the following two centuries more than one hundred different attempts were made by an almost equal number of astronomers, mathematicians, mechanics, self-taught scientists and noblemen; most of them were unreliable, fragile, expensive and could not compete with paper-and-pen computing.

4 Besides the names mentioned above: Baldassarre Lanci (1557), Antonio Bianchini (1564), Carlo Teti (1575), Antonio Lupicini (1582), Latino Orsini (1583), Ostilio Ricci (1590), Ottavio Fabri (1598). (Camerota, 2000).

5 Christopher Schissler (1566,1580), Jost Bürgi (1588), Thomas Hood (1598), Christopher Scheiner (1603), Michel Coignet (1610) (Drake 1999, p. 7, Camerota, 2000, pp. 124-125).

${ }^{6}$ Early mechanical clocks were known in Italy in 14th century, in Milan (1335) and Padua (1364). 
In Museo Galileo's collection in Florence ${ }^{7}$ visitors can admire a beautiful and bizarre brass object in the shape of baroque frieze with small dials on its face. The tag says: 'N. 3179, Tito Livio Burattini (attr.) Calculating machine, First half of 17th cent.' The machine has nine main dials, the upper six numbered $0-9$, the lower three 0-6, 0-19 and 0-11 respectively. Paired with each main dial is a smaller one, likewise numbered. The instrument is a 'money adder' of the kind Samuel Morland (1625$1695)^{8}$ built in London in 1673 and described in a booklet (Morland 1673; Williams 1997, pp. 136-140). Unlike pascaline, both N. 3179 and Morland's machines have no mechanism to transmit 'carry' from one digit to the next, but only auxiliary small dials moving one position at every turn of the respective main wheel. The 10 positions dials are for lire (pounds) and the 20 and 12 positions dials are for soldi (shillings) and denari (pence); the uncharacteristic 7 position wheel was possibly used for the conversion of Florentine lira to ducato ${ }^{9}$ ( 1 ducato $=7$ lire $)$ (Cipolla 1987, p. 131) or of German schillings to gulden $(1$ gulden $=7$ schillings $)$ (Schäring 2003, p. 94).

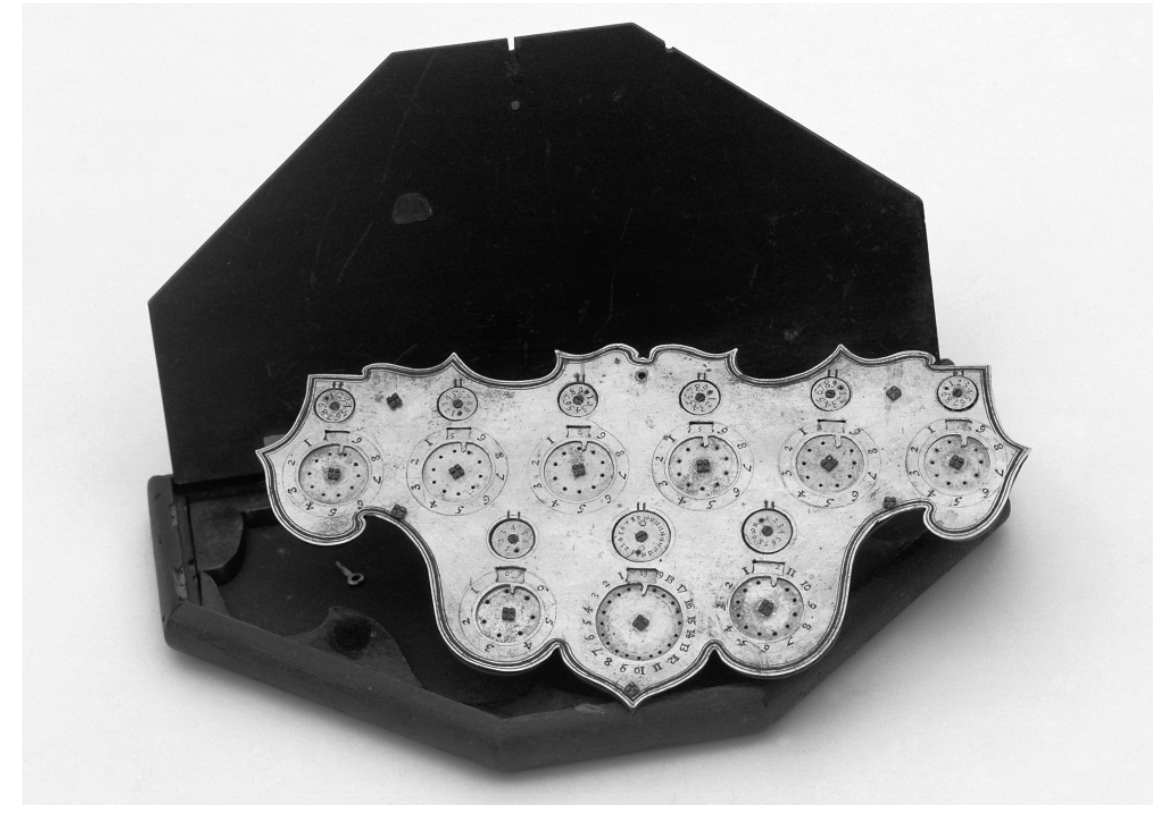

Fig. 3. Dial adder attributed to Tito Livio Burattini (Museo Galileo, Florence, - Photography Franca Principe)

\footnotetext{
${ }^{7}$ Now 'Museo Galileo', Florence, http://www.museogalileo.it/en/index.html, Accessed January $14,2012$.

${ }^{8}$ Morland gifted two mathematical instruments to Cosimo III De' Medici, now at the Museo Galileo in Florence.

${ }^{9}$ Ducato was the currency in Florence, lira was a fictitious unit for bookkeeping and money exchange.
} 
Tito Livio Burattini (1617 - 1681) was an Italian polymath, egyptologist, inventor, instrument maker, architect and engineer who left his birthplace - Agordo, a small village in the North of Italy - to travel to Egypt and Germany and eventually settled in Poland at the court of King Wladyslaw IV where he was appointed chairman of the Polish mint (Tancon 2005). In 1675 Burattini suggested a universal length unit he dubbed metro cattolico (universal meter), ${ }^{10}$ well in advance of the French metric revolution of 1793. He also built a flying machine, in every respect a glider, and made lenses for telescopes and microscopes, presenting them to Cardinal Leopoldo de' Medici. Burattini corresponded with many scholars and philosophers all over Europe and kept himself informed of scientific and technical achievements.

In 1647, while in Krakow, Burattini had the opportunity to scrutinize one pascaline, gifted by Pascal to King Wladyslaw's wife, Maria Luisa Gonzaga. He then decided to adventure upon building one himself; in 1658 he succeeded to finish a model with eight dials 'like Pascal's contrivance' (Targosz 1992, pp. 164-165) and sent it to Grand Duke Ferdinando II de' Medici. In fact, two letters from Alfonso Borelli ${ }^{11}$ to Cardinal Leopoldo de Medici, Ferdinando's brother, dated November 15 and December 1st, 1658, mention an 'istrumento o cassettina numeraria' [instrument or small box for numbers] sent by Burattini. Burattini's gift was wrote down on the inventory of the de' Medici's collection ${ }^{12}$ in 1660 : 'N.585 in data 1659 uno strumento di ottone per fare abaco ${ }^{13}$ che ha otto ruote, lungo 3/4 largo 1/5 a S.A: serenissima donato da Tito Livio Burattini il 22 giugno' [N. 585. In 1659 a brass instrument for calculation with 8 wheels, $3 / 4$ long and $1 / 5$ wide $^{14}$ presented to His Serene Highness [Ferdinando II de' Medici] by Tito Livio Burattini on June, 22]. The same description is repeated in later catalogues (1704 and 1738). In 2007 the historian Vanessa Ratcliff noticed (Ratcliff 2007) that the object recorded on the 1660 inventory do not match with N.3179: the number of wheels of the latter is nine (eighteen if the nine small dials are taken into account), instead of eight. Moreover the size of N.3179 $(20 \times 10 \mathrm{~cm})$ do not fit with those recorded in $1660(44 \times 12 \mathrm{~cm})$. It is also worth noting that the $1660 \mathrm{~s}$ specimen has, more or less, the size of the eight-wheel pascalines $(36 \times 12 \mathrm{~cm})$ (Marguin 1994, p. 62) Burattini tried to reproduce. Interestingly enough in a catalogue of 1779 [Real Gabinetto, 1776-1779] the description is without a doubt different : "Una macchinetta forse aritmetica di due lastre di ottone centinate che racchiudono 18 cerchi tra grandi e piccoli, numerati, imperniati, e da muoversi a mena dito. La macchinetta ha la faccia dorata, ed è lunga nel più pollici 7.3.." [- a small machine, perhaps arithmetic, made of two ribbed brass plates that enclose 18 large and small circles, numbered, hinged and to be operated with fingers. The machine has golden face and is 7.3 inches long (ca. $21 \mathrm{~cm}$ )]. The new description fits well with the object N.3179. It is noteworthy that in 1737 the last Medici, Gian Gastone, died and

${ }^{10}$ Equivalent to the length of a free one second pendulum, as the English philosopher John Wilkins proposed in 1668.

${ }^{11}$ Giovanni Alfonso Borelli (1608-1679) was a mathematician and philosopher in Rome.

12 The Medicean collection was started by Grand Duke Cosimo I in $16^{\text {th }}$ century.

${ }^{13}$ In Renaissance Italian 'fare abaco' meant 'to compute', thus synonym of arithmetics, even if abacus was not used.

${ }^{14}$ Taking the Florentine unit (braccio da panno $=58,3 \mathrm{~cm}$ ), it is $\mathrm{cm} \mathrm{43,8}$ x 11,7. Even with different units the aspect ratio is inconsistent with N. 1379. 
the Grand Duchy of Tuscany was entrusted to the House of Habsburg-Lorraine; nine years later almost all the Medicean scientific collection was moved to the Imperial Museum of Physics in Vienna, ${ }^{15}$ never to return (Bedini 1995). In the meantime the Florence collection was enriched with hundreds of pieces from the Lorrainese Chamber of Physics of Lunéville, under the supervision of Philip Vayringe ${ }^{16}$. Thus we can conclude that Burattini certainly made a pascaline-like calculator and sent it to Florence where it remained for more than a century, but sometime before 1779 it disappeared (sent to Vienna ?) and was replaced with the actual N.3179. As for the origin of the latter, Ratcliff suggests that it can be attributed to an unknown Italian maker or to Samuel Morland - due to the similarity with his money adders — but a third possibility is that N.3179 comes from Lunéville, perhaps due to Vayringe or another Lorrainese maker.

\subsection{Giovanni Poleni’s Calculator (1709)}

In December 1709 a booklet was printed in Venice bearing the title Miscellanea (Poleni 1709); one of the three chapters is the description of a calculating machine invented by the author, Marquis Giovanni Poleni (1683-1761). Poleni was born in the Republic of Venice, son of a wealthy man titled marquis by the Emperor Leopold I of Augsburg. Not much interested in political career, Poleni preferred the study of physics, architecture and mathematics. In 1709, thanks to his book, a sort of doctoral thesis, Poleni was appointed professor of astronomy and meteorology at the University of Padua, where he worked until his death as professor of physics, mathematics, experimental physics and naval engineering. In Padua he founded one of the first European laboratories of physics, certainly the best equipped with more than 400 fine instruments. Marquis Poleni was renowned in European scientific milieu and was a fellow of the Royal Society, the French Académie des Sciences and the Prussian Academy of Sciences (Soppelsa 1963; Soppelsa 1983).

At the age of twenty-four Poleni heard news of Pascal's and Newton's calculators ' from scholars in person and from their writings' ${ }^{17}$ and, though having no drawings nor technical description of the two previous inventions, decided to design and build an original one. After some attempt, the machine was finished in 1709. Poleni's calculator - in the shape of a big grandfather clock, in wood and iron - is a four-operation device, enabling the user to perform additions, subtractions (resorting to complement-to-nine additions), multiplications (by multiple additions), and divisions (by multiple subtractions) (Poleni 1709; Soresini 1971, pp. 95-105; Bonfanti 1988, Hénin 2009). To perform multiplication and division Poleni followed, independently, Leibniz's idea of a device where multiplicand and divisor could be stored and to be added or subtracted a fixed number of times. Differently from Leibniz' 'stepped drum', the marquis conceived the 'pinwheel', a wheel with an

\footnotetext{
${ }^{15}$ Francesco II Stefano Grand Duke of Tuscany was also Emperor of the Holy Roman Empire, and King of Austria.

${ }^{16}$ Philip Vayringe (1684-1746) was court mechanician and clockmaker of the Duke of Lorraine and professor of experimental physics in Lunéville. Vayringe followed the Duke to Florence where he took care of Medicean collections.

${ }^{17}$ Perhaps from John Wallis' 'Opera mathematica' (1695) (Gennari, 1839).
} 
adjustable number of teeth (0-9) that could be raised or lowered to set the figure to be operated upon. Poleni's machine had a three-sector wheel, thus enabling to set a three-digit figure, and a clockwork mechanism - with verge escapement - to drive the entire machine by the energy of a falling weight. The pinwheel, albeit with different design, was implemented in a number of calculators in the following three centuries, e.g. the popular Baldwin-Odhner architecture (Williams 1997, pp. 146-149, Hénin 2009). Poleni's Invention was acknowledged in Europe thanks to its description published in 1727 in the first comprehensive review on mathematical instruments by Jacob Leupold (Leupold 1727, pp. 27-35).

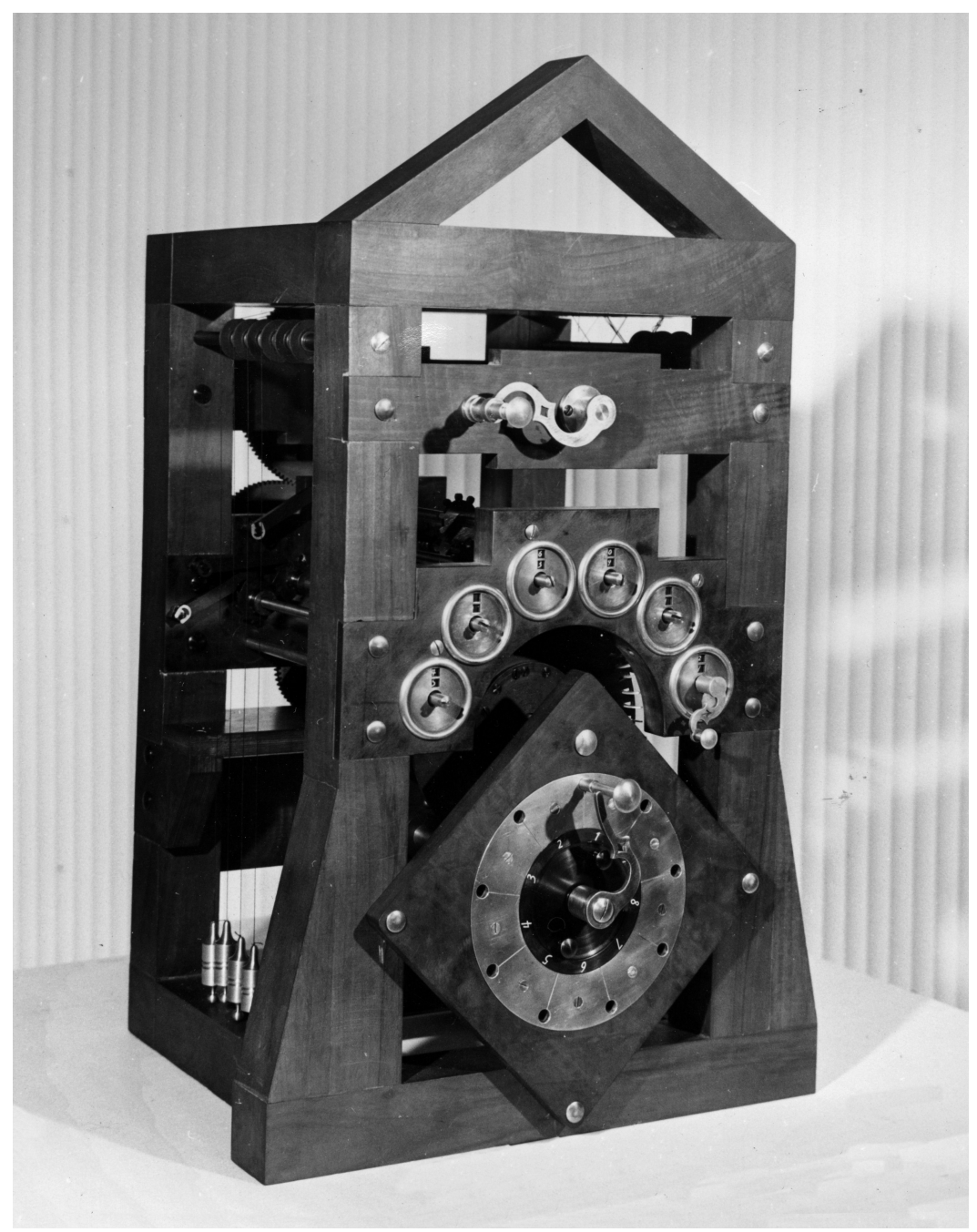

Fig. 4. Giovanni Poleni's calculator (1709). Replica of 1959 (Courtesy of Museo Nazionale della Scienza e della Tecnologia "Leonardo da Vinci", Milan) 
As Poleni's biographers recount (e.g. De Fouchy 1763, pp. 152-153), after some years the Italian physicist was informed of a similar, but better machine built in 1727 by the Austrian Anton Braun, court mechanic of Emperor Karl VI in Vienna; having known this Poleni 'smashed his machine into pieces and never built it again'. Around 1720 Braun worked in the Grand Duky of Milan (North Italy) as a surveyor, under the supervision of the imperial engineer Johann Jacob Marinoni, and possibly got information of Poleni's machine (Marinoni was in correspondence with Poleni and perhaps visited him in Venice) (Habacher 1960). Nevertheless Braun's calculator, although resorting to pinwheels, was for many other features quite different from Poleni's: much smaller, all metal, hand driven; thus a possible plagiarism, but of the general idea, can be ruled out. Moreover Poleni's temper was neither cantankerous nor vengeful and his reaction could be ascribed to sincere appreciation of the technical superiority of Braun's contrivance. The lost Poleni's machine was reconstructed in 1959 by Franco Soresini thanks to the help of IBM Italy and Museo Nazionale della Scienza e della Tecnologia in Milan (Soresini 1991); after another 50 years the replica was restored and successfully put into action (Hénin 2009).

\subsection{Bernardo Facini's Slide Rule (1714)}

Bernardo Facini (1665-1731) was an astronomer, mathematician and skilled instrument designer who worked in Venice. To him several mathematic instruments for navigation, survey and time measurement have been attributed, some of them still in museums in Europe and United States (Anastasio 1994). In 1714 Facini designed a circular logarithmic slide-rule, now at the Adler Planetarium in Chicago. After the invention of logarithms by John Napier in 1614 and their perfection by Henry Briggs, the idea of a device exploiting their properties to mechanize computing — as alternative to logarithm tables - soon arose: the first by Edmund Gunter (1620), followed by Richard Delamain's (1630) ${ }^{18}$ and William Oughtred's (1632), both of circular shape (Williams 1997, pp. 105-110). The first circular slide rule with a spiral scale, to increase effective length (and precision) without increasing overall size too much, is due to Milburne (1650) (Horsburgh 1914, p. 155). Facini's design is a very simple one: a brass disc of $22 \mathrm{~cm}$ diameter brings a number scale (1 to 10) and a logarithm scale (0 to 1$)$, respectively on the two sides. Two movable pairs of dividers, one for each side, are hinged in the disc center to help setting numbers. Scale divisions are such that a three-four digit precision can be obtained, with the help of a transverse vernier engraved on number scale. (Righini 1980). Thanks to the spiral scale, Facini's device is equivalent to a $100 \mathrm{~cm}$ long linear rule.

\section{$5 \quad 19^{\text {th }}$ Century: Advanced Mechanical Calculators}

In Eighteenth Century Italian science and technology underwent a slowdown; some historians try to explain the phenomenon with Galileo's conviction for heresy, but this cannot be the only reason, nor the main: political division and a general state of

18 The priority, and possible plagiarism, between Delamain's and Oughtred's inventions is still debated. Oughtred was helped by his pupil William Foster. 
recession also contributed. The beginning of 19th century saw, luckily, a revival, particularly in technology and applied science, thanks to the founding of several new institutions for education, training and promotion of technical and industrial advancement. Almost all these bodies - akin to the French Conservatoire des Arts et Métiers - were established by Napoleonic governments but, happily enough, survived Napoleon's fall and 1814 European Restoration. Those institutes flourished in particular in Lombard-Venetian Kingdom and in Grand-Duchy of Tuscany.

\subsection{Luigi Torchi's Keyboard and Direct-Multiplication Calculator (1834)}

All we know about Luigi Torchi's life (1812-?) is that he was an uneducated mill carpenter working in the suburbs of Milan. In 1834 Torchi was awarded the Golden Medal by the Royal-Imperial Lombard Institute of Sciences, Letters and Arts for the invention of a calculating machine (Hénin 2010a). In the following years Torchi invented other two contrivances: a horse-less cart that, moving along the canal towing-path, dragged a barge, exploiting the energy of the canal's stream; the invention was acknowledged in Italy and France and was awarded a silver medal by the Lombard Institute in 1837. In 1858 Torchi also built an improved pendulum level. Two descriptions only of Torchi's calculating machine have been found: the jury's handwritten report ${ }^{19}$ for the prize and an anonymous article on the magazine La Fama (La Fama 1840), where an artist impression of the machine was printed. From the two sources and the picture an attempt to understand the principles of action has been made (Hénin 2010a). First of all the calculator makes use of an extended keyboard four rows of nine keys — to enter numbers up to 9999. The earliest keyboard calculating machines reported in literature are those by Jean-Baptiste Schwilgué (1844) (Roegel 2008), Du Bois D. Parmelee (1850), Victor Schilt (1851), Thomas Hill (1857) (Turck 1972), all were 'column adders' conceived to carry out additions of single-digit addenda without tens-carry mechanism, differently from Torchi's, which can sum up four-digit numbers. The second and more impressive feature is the ability to perform direct multiplications, without resorting to multiple additions. In fact, the jury's report state that “... a device is conceived that gives the product of that figure by each of the nine simple numbers ... [the multiplication] is obtained by means of pinions ... "[author's underscore], in accordance with the mode of use described in La Fama (La Fama 1840). Early direct multiplication machines were conceived forty years later by Edmund Barbour in 1872, followed by Ramon Verea (1878), Léon Bollée (1889) and Otto Steiger (1892) (Turck 1972, p. 181; Soresini 1971, pp. 125-132; Marguin 1994, pp.130-134).

Torchi's calculator gathered much local interest: a sum of 1000 lire was appropriated by the government for an improved model in metal - the prototype being in wood - and the Milanese Census Board asked for another to help land surveying, but the inventor was possibly not skilled enough to satisfy the requests. The machine was publicly exhibited in the next decades until found by astronomer Giovanni Schiaparelli in 1872, but "lacking many pieces, almost all the front part containing the device

${ }^{19}$ The whole dossier is collected at the Historical Archive of the Lumbard Institute, in Milan. 
for the preparation and the reading of the results is missing" (Henin 2010a). Built with perishable materials and already damaged in 1872 , the calculator was probably shattered or disposed and no traces of it have yet been found.

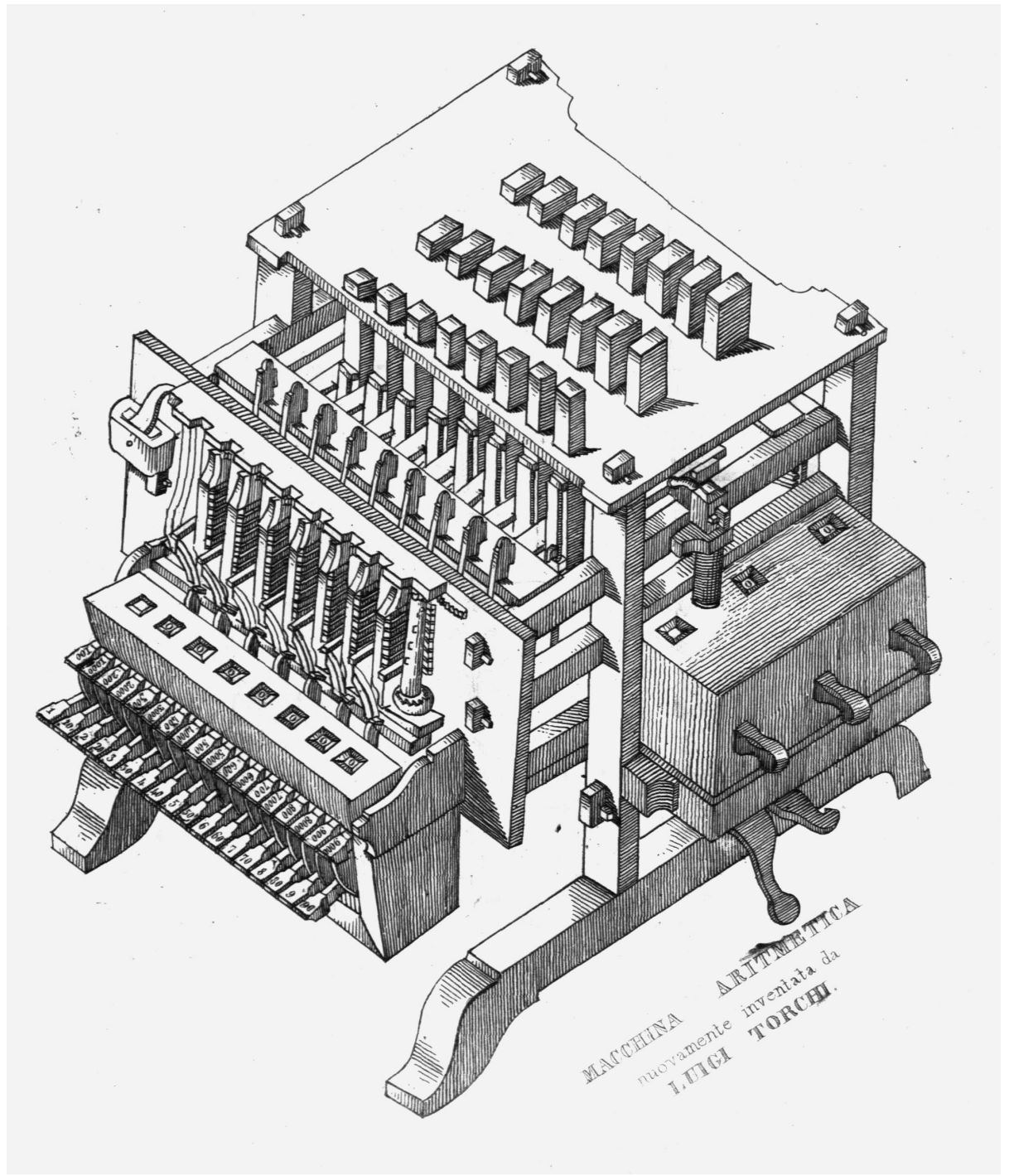

Fig. 5. Luigi Torchi's direct mutiplier (1834) (La Fama 1840) 


\subsection{Tito Gonnella's Analog and Digital Machines (1825-1859)}

In another Italian State, the Grand Duky of Tuscany, technology was appreciated and technical development stimulated by an active network of institutions and schools; Florence hosted also several skilled instruments makers. One of those was Tito Gonnella (1794- ca. 1867), professor of mathematics and mechanics at Accademia di Belle Arti in Florence (Borchi 1997), who made also an improved Newtonian reflection telescope. In 1825 Gonnella published a paper (Gonnella 1825) describing an early planimeter or 'machine to square plain surfaces' to calculate the surface area of any closed figure. Planimeters were the most common instrument available in the $19^{\text {th }}$ Century; they gave the area of irregular figures, useful for surveyors, and were soon employed as mechanical integrators for mathematical functions (Carse 1982; Bromley 1990).

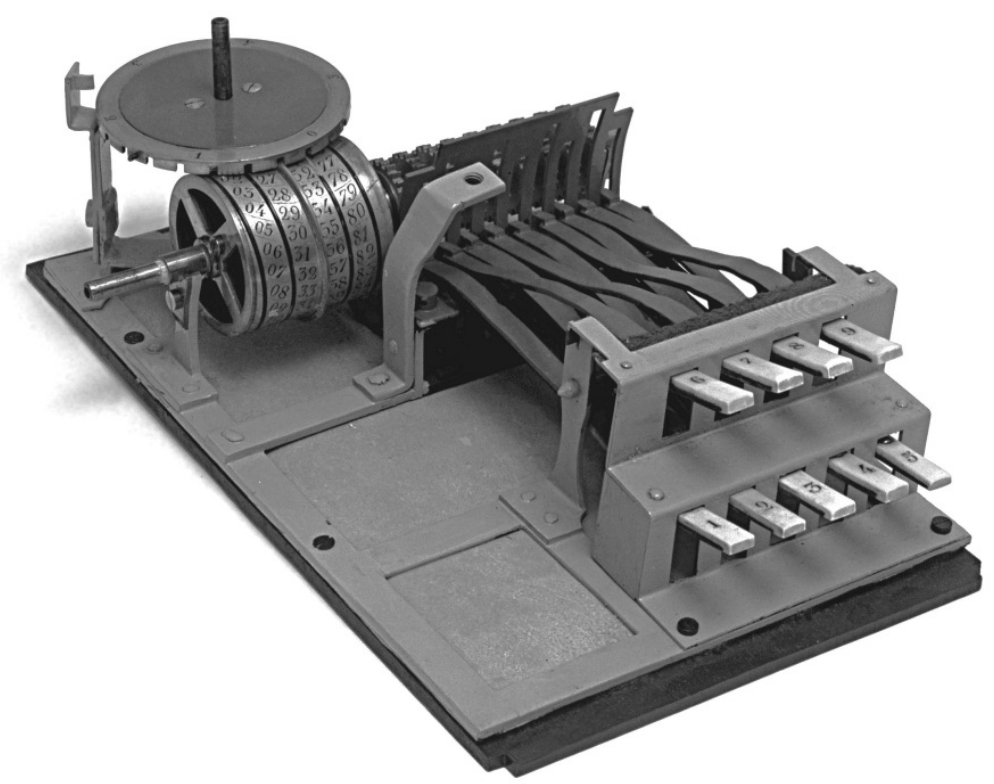

Fig. 6. Tito Gonnella's keyboard adder (1859) (Museo Galileo, Florence, - Photography Franca Principe)

An earlier model of planimeter was invented by Johann Martin Hermann in 1814 but remained almost unnoticed. Gonnella's design was based on the so called 'disk-andwheel' mechanism, after having tried the 'disk-and-cone' and discarded it for the lack of precision. In the following decades, Gonnella exhibited his planimeter in various instances, e.g. the 1851 Great Exhibition in London, where his invention was awarded with the Council Medal, and Paris Exposition Universelle in 1855. Gonnella had only one planimeter built in Florence, then he realized that the construction of his instrument required the precision of Swiss manufacturers and sent his drawings to some of them, amongst whom Johannes Oppikofer, who designed a planimeter in 1827. Henrici 
(Henrici 1894) suspects that Oppikofer's device was 'strongly influenced' by Gonnella's. That of planimeters and integrators is another case of multiple, more or less independent, inventions; in London Great Exhibition four planimeters were shown, by John Sang, Kaspar Wetli, Jean Antoine Laur and Ausfeld ${ }^{20}$.

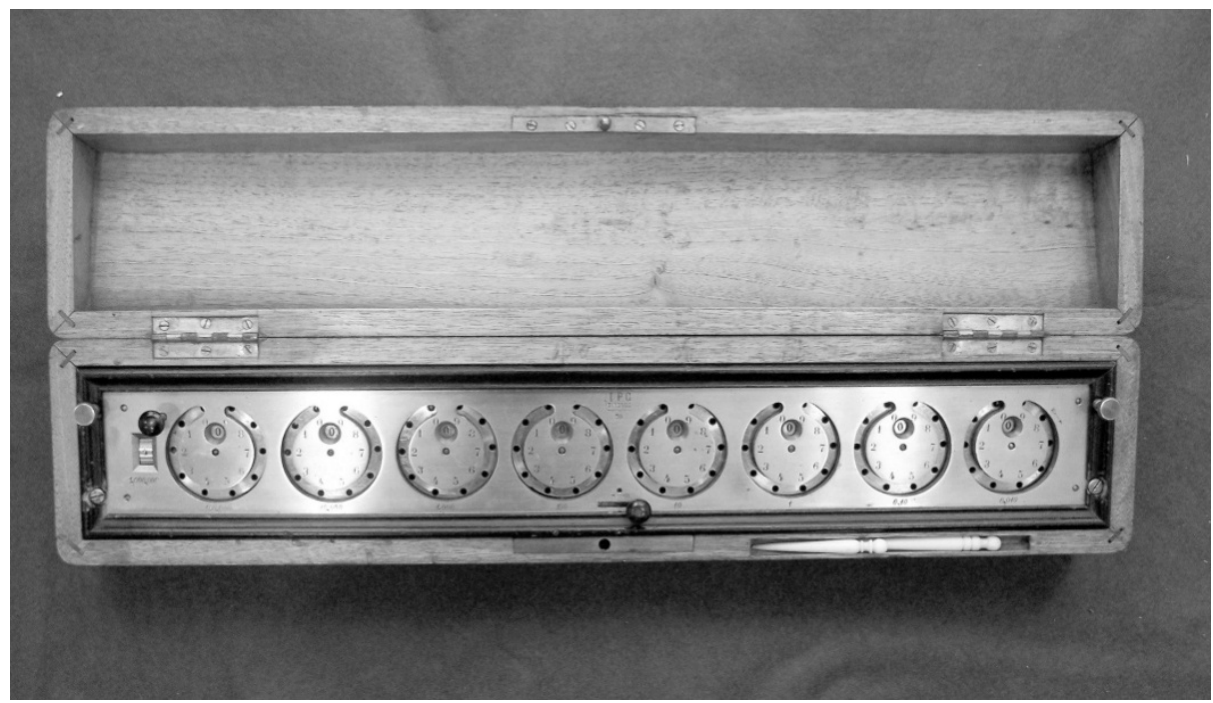

Fig. 7. Tito Gonnella's dial adder (1859) (courtesy of Arithmeum, Rheinische FriedrichWilhelms-Universität, Bonn)

Gonnella's other contributes to calculator technology were two small machines he described in a booklet (Gonnella 1859). The first is a dial adder, akin to Pascal's invention and to many others, three exemplars were finished in 1857 and shown in public. The carry transfer mechanism is unique and original, but still unreliable: in case of ripple carry (e.g. adding 99999+1) it tends to jam; the inventor acknowledged this flaw and tried to correct it with an anti-jamming device. Until recently the machine was thought lost, but in 2010 the author found one at the Arithmeum in Bonn (Germany), already described by Hans-Joachim Vollrath (Vollrath 1997), but not yet ascribed to Gonnella. The ascription is still not assured for some small particulars are different from Gonnella's original drawings (Hénin 2012), but, although not original, it was certainly based on Gonnella's design. The second calculator described in the booklet is a keyboard single-digit adder (column adder) (Hénin 2010a), akin to Parmelee's prototype (Turck 1972, pp. 16-29), but with a different mechanism: nine keys moved, via as many toothed sectors, a numbered helical drum to add digits up to 599. The small and simple machine is now in the collection of Museo Galileo ${ }^{21}$ in Florence, still in good conditions. Both Gonnella's digital calculators were exhibited several times in the second half of $19^{\text {th }}$ century.

\footnotetext{
${ }^{20}$ Exhibition of the Works of Industry of all Nations, 1851: reports by the juries on the subjects in the thirty classes into which the exhibition was divided. Clowes, London, 1852.

${ }^{21}$ Previously known as 'Museo di storia della Scienza'.
} 


\subsection{Niccola Guinigi and His One-of-a-Kind Calculator}

Count Niccola Guinigi (1818-1900) was born in Lucca (Tuscany), offspring of a powerful and wealthy merchant family who ruled the city since $15^{\text {th }}$ century ${ }^{22}$. Few scattered information can be gathered about Niccola's life and almost nothing can be found about his possible technical and scientific interests. ${ }^{23}$ On January 16, 1659 Count Guinigi submitted a calculating machine of his invention to the Accademia Toscana di Arti e Manifatture in Florence, the calculator was scrutinized by two Accademia's referees ${ }^{24}$ who found it "particularly commendable for its simplicity and robustness", but suggested improvements to overcome some flaws (Corridi 1859). After that date no other record of Guinigi's contrivance can be found, but a letter by Tito Gonnella (Gonnella 1859) to the Accademia, claiming priority over Guinigi. In spring 2010 the author serendipitously came across the forgotten Guinigi's machine in an antique shop in Milan (Hénin 2012), with autograph notes by Guinigi, and was granted the opportunity to examine it. The calculator is a dial adder of unique architecture; in fact it has a single large dial to be turned by hand to enter each digit of the addenda and the decimal order of magnitude is selected by eight mutually exclusive levers. As in the case of Gonnella's dial adder, Guinigi's suffers from ripplecarry jamming and the inventor tried to solve the problem with two levers to prevent it. No other dial adder with such a feature has been reported in the literature. The making of Guinigi's adder is all in wood with small metal details (springs and screws) but, after 150 years, still in good and almost working conditions. Guinigi's machine has recently been acquired by Arithmeum in Bonn (Germany).

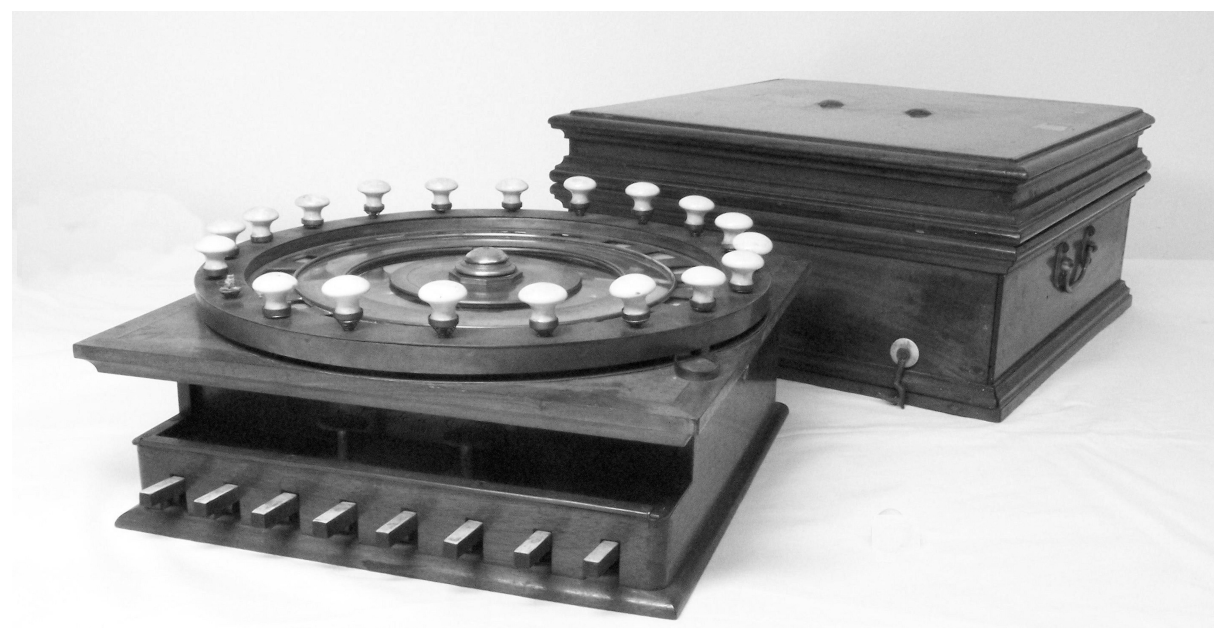

Fig. 8. Niccola Guinigi's dial adder (1859) (courtesy of Arithmeum, Rheinische FriedrichWilhelms-Universität, Bonn)

\footnotetext{
${ }^{22}$ Niccola's most famous ancestor was Paolo Guinigi (1372-1432).

${ }^{23}$ Neither printed works nor manuscripts have been published under his name.

${ }^{24}$ The mathematicians Giovanni Novi and Antonio Ferrucci.
} 


\subsection{Other $19^{\text {th }}$ Century Italian Inventors}

Several other inventions are briefly mentioned in contemporary literature: In 1824 Benedetto Isidoro Brun submitted to the Istituto Lombardo di Scienze e Lettere, the invention of a keyboard calculator, in 1832 abbot G. P. Genevois submitted a simpler one for the four operations and in 1833 Carlo Mezzanotte tried with his portable calculating machine. Giuseppe Mozzoni was another Lombard inventor who was awarded a medal in 1847 for a small mechanical adder. The Turinese Luigi Palagi Palmarini in 1829 was granted a ten years patent (privilegio) by the government of the Kingdom of Sardinia for a computing machine. A watch maker from Mondovì (near Turin), Opprandino Musina, exhibited a pocket dial adder at the Exposition Universelle of 1867 in Paris, a short description has been published by the American Committee officially appointed to report on the exhibition (Barnard 1869). Musina's was another prototype of small dial-adders of the pascaline kind. For all the a.m. names, unfortunately, coeval printed sources are scant, inaccurate and often unreliable; a long effort to search several scattered local archives for more information would be required.

A different kind of computing machinery was in the meantime appearing, for statistical data processing: the 'punched card' technology invented by Herman Hollerith (Austrian 1982). Hollerith's invention of 1889 was well known in Italy thanks to his friendship with the Italian statistician Luigi Bodio and an attempt to use punched card tabulators was proposed by Bodio for the Italian census of 1891 (Hénin 2010b). Unluckily, scarce resources were available and the census was postponed. Ten years before and independently, one of Bodio's collaborators, Luigi Perozzo (1856-1916), invented a mechanical tabulator to be used for 1881 census, but finished one year later. It was a desk-like device with 144 mechanical counters, each identified by a label for a particular item to be counted (e.g. age, nationality, job, marital status ...) . The census clerk read the data collected and pushed the proper counter, increasing it by one unit. When a group of data were finished the clerk put a large paper form on the desk and pressed it against the counters, previously inked, and the results were printed on the form. Perozzo's tabulator never went into use, but his idea was taken by the Frenchman Lucien March few years later (1899) and was widely used both in France and Italy. In a letter of 1904 to Ministère du Commerce de l'Industrie, March acknowledged Perozzo's priority (Pietra 1934).

\section{$6 \quad 20^{\text {th }}$ Century: The Rise of Industrial Inventions}

Almost all the Italian inventors, but Torchi and (perhaps) Galileo, we have seen so far were scholars or noblemen who attempted the construction of calculating machinery more to satisfy their curiosity and to challenge their ingenuity than to obtain a reward or income, they were often not in the need of. Moreover in Italy a possible market for their instruments was certainly negligible. It was only after 1850 - even more after the political unification in 1861 - that Industrial Revolution reached Italy, particularly in the Northern regions, with the appearance of railway networks, electric power plants, big industries and technical high-schools. Thus, inventions no longer were the activity of secluded amateurs, but became a professional undertaking strictly connected to industrial production, marketing and entrepreneurship. 


\subsection{Fossa-Mancini's Adder and Taeggi-Piscicelli's Electromechanical Calculator}

Count Carlo Fossa-Mancini (1854-1931) was an engineer, physicist and political philosopher. In 1893 he invented an innovative dial adder (Soresini 1971, p. 60; Celli 2006; Jacob 1911, pp. 17-19; Martin 1925, p. 129), where the dials were no longer on the same plane on different vertical axles, like the pascaline, but vertically arranged on one common horizontal shaft. Digits were set by turning the dial borders, thanks to pins on the dial edge. This architecture allowed quick setting of operands, prevented carry jamming, and permitted a more compact structure of the calculator. In 1899 Fossa-Mancini applied for a British patent, granted the same year [Pat. N. 189904489, July 1, 1899]. A small scale production (perhaps a few hundred) was made by the French company Japy Fréres \& Cie - a producer of clocks, farm and house appliances - beginning of 20th century. The calculator do not seem to have obtained a sensible sale success and production soon came to an end, but decades later Fossa-Mancini's design was resumed by several producers in Italy (Brevetti Lanza's Addipresto), Germany (Addi, Comet, Argenta), USA (American Adder, ToddStar, Little Geant), Japan (Addimat) and Hong Kong (Swift Handy), until the mid1950s (Celli 2006). All those 'clones' were cheap, reliable and easy to use. Of the original, Japy-made calculators only a few still remain: one of them is exhibited in the museum of Castelplanio, Fossa-Mancini's home town; another one has been recently offered on an internet auction site (March 2012).
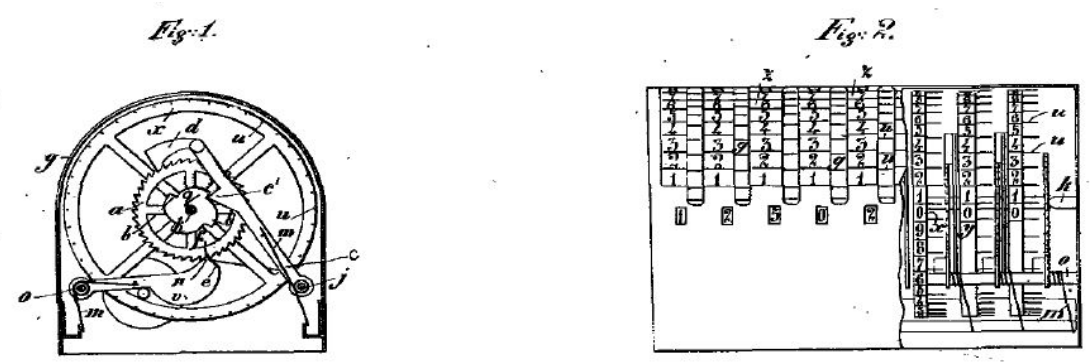

Fig. 9. Fossa-Mancini's calculator (1899) (UK Patent n. 4489, 1899)

Another forgotten inventor was the Neapolitan Count Roberto Taeggi-Piscicelli (Celli 2010; Martin 1925, p. 263), nobleman and engineer who was also political activist and economist. In 1903 Taeggi-Piscicelli invented a cash register patented in USA (US. Pat. N. 872845, granted 1907) the rights were later sold to the American National Cash Register Co. In 1911 the inventor submitted another patent in Germany, Austria and United States for an electrical motor-driven calculator (US. Pat. N. 1416974) one of the earliest electromechanical machine, perhaps the second after the Autarith created in 1902 by the Czechoslovakian Alexander Rechnitzer. Taeggi's machine, with the brand name Sanders, was manufactured by the French Société Industrielle des Téléphones. 


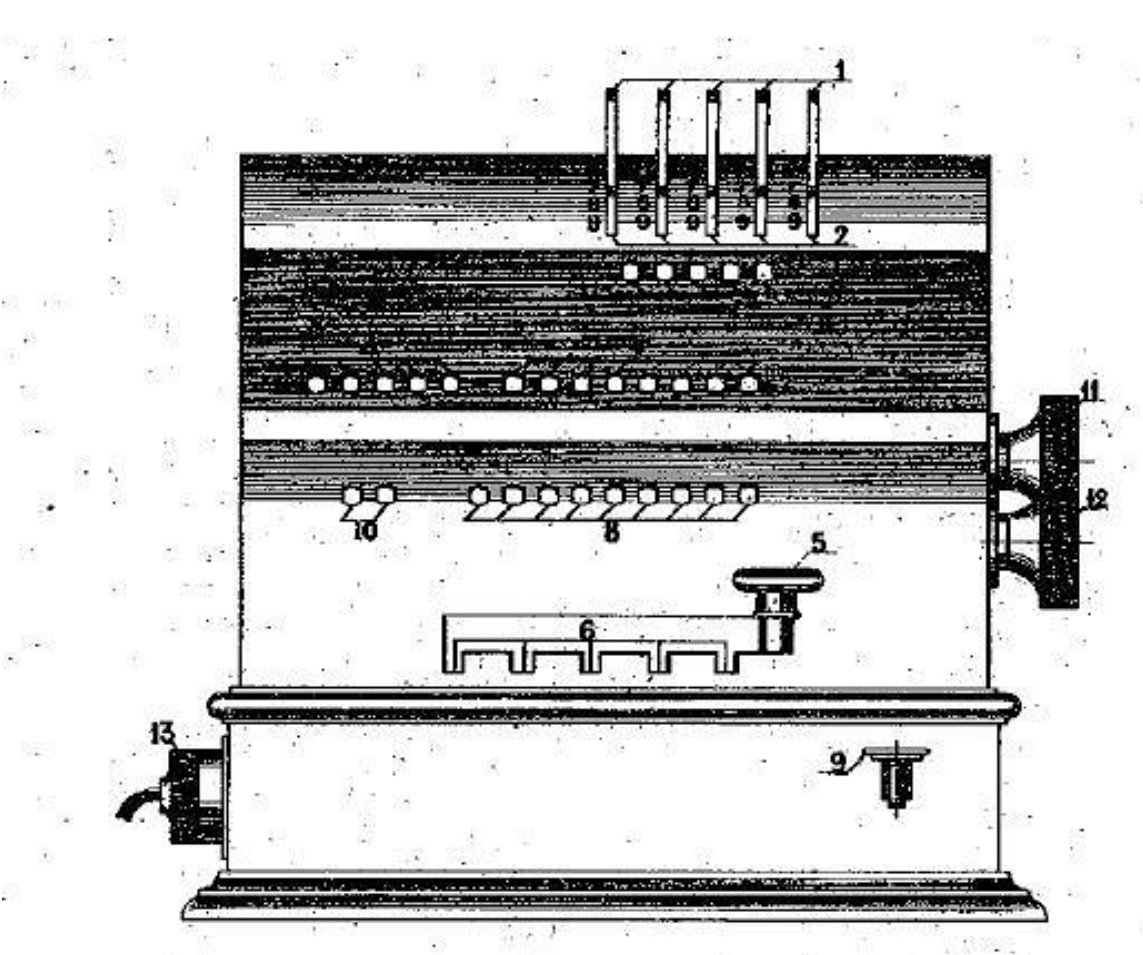

Fig. 10. Taeggi-Piscicelli's electrical calculator (1912) (British Patent n. 10148, 1912)

\subsection{The Rise of the Italian Calculator Industry}

In spite of Italian inventiveness and of growing national market, no calculator industry was created before 1930 . It was only with the autarky enforced by the fascist regime - protectionism due to the economic crisis of 1929 and to the embargo imposed by the League of Nations as a consequence of the Italian-Abyssinian war of 1935 - that an effort to create national industries to minimize import from abroad was carried on. As a matter of facts, both causes were not so severe - the embargo lasted only a few months and was strictly observed by Great Britain only - but fascist propaganda exploited autarky as a stimulus for national pride and popular consensus. Thus, after 1930 a bunch of Italian manufacturer ${ }^{25}$ came up (Torchio 1999), producing several models of full-keyboard (Comptometer's style) and reducedkeyboard adders (printing and non-printing) and also four-operations machines (Brunsviga's style). Their market was almost restricted to Italy, with limited export, and some of the models were manufactured on foreign patent licenses. The outbreak of WWII possibly caused some of those companies to switch the production to light weapons, ammunitions and other warfare technology. After the end of WWII and the

${ }^{25}$ Addicalco, Invicta, Italcalcolo, Serio, Inzadi, Ducati, F.A.C.S.A., M.U.S.A., Pozzi, PSIC, SIMAS-Stiatti (Celli, 2006). 
following reconstruction, giving rise to the 1950 s - 1960s economic boom, other producers entered the market with more advanced technology and electromechanical models ${ }^{26}$. Cash registers were also produced in Italy since 1925 by SIR (Società Italiana Registratori) and since 1936 by RIV (Società Anonima Officine di Villar Perosa), designed and patented by Biagio Beria (Celli 2010).

Only one Italian company was able to reach a world-wide market: Olivetti. Founded by Camillo Olivetti in 1908 for the production of typewriters, with the headquarters in Ivrea, near Turin, Olivetti was one of the most successful Italian manufacturer, renown not only for its products but also, and mainly, for its forefront management style and top level industrial design - several Olivetti's products are shown in international art museums and exhibitions - particularly under the guide of Camillo's son Adriano in the post-WWII era (Ochetto 2009; Semplici 2001). In 1935 Adriano Olivetti realized that, although successful in the typewriter market, his company was missing the opportunity of other office appliances, like desk top calculators. The first mechanical calculator was produced in 1940 (the MC 4 Summa) designed by Riccardo Levi with the help of a young uneducated, but ingenious worker: Natale Capellaro. After WWII Olivetti brought out a series of innovative electromechanical models (e.g. Divisumma, Logos, Elettrosumma,) and some complex bookkeeping machines (Tetractys), almost one new model every two years, until 1965, thanks to Capellaro's great ingenuity. Indeed Capellaro's contribution was highly prized in Olivetti ensuring him an unbelievable career for a blue collar with just an elementary education. Capellaro joined Olivetti in 1916 as apprentice worker, in 1943 was appointed Head of Project Office, then Technical Director in 1960, and was awarded the degree honoris causa in engineering at the University of Bari in 1962 (Silmo 2008; Salvetti 2002). Capellaro is author of more than thirty Olivetti's patents; thanks to him, Olivetti's machines had two main advantages over competitors: they were much more reliable and fast, although still electro-mechanical, and their manufacture was cheaper, permitting both a lower selling price and a higher profit (production cost of Divisumma 24 was one tenth of selling price). Due to these advantages Olivetti in 1956 exported more than $30 \%$ of its production and near 6 million dollars worth of calculating machines were sold in US the same year (Cortada 1993, pp. 251-255).

\section{$7 \quad$ Other Inventions of the $20^{\text {th }}$ Century}

\subsection{Annibale Pastore's Logical Machine (1906)}

After the publication of George Boole's 'Mathematical Analysis of Logic' in 1847, the discipline no longer pertained to philosophy but became the job of mathematicians; with the new symbolic logic notation, syllogisms could be solved by mathematical procedures, and algorithms can be, in principle, carried out automatically by

26 Aldo Bona, ELMIS, ELMETECNIL, SAMAS, Steiner, Serio S.p.A., Luini, FACSA, I.M.C.A., Industria Calcolatrici Scriventi, Peghetti-Corsini (Celli, 2006). 
mechanical devices. Already in the second half of $19^{\text {th }}$ Century the British economist Stanley Jevons built a mechanical 'logical piano' to solve simple problems of class logic, followed by the American Allan Marquand who, in 1885, designed another logical machine, this time electromechanical (relay based), anticipating Claude E. Shannon's studies of fifty years (Gardner 1958; Buck 1999, Maas 2005, pp. 96-150). The Italian philosopher Annibale Pastore (1868 - 1956), later professor of theoretical philosophy at the University of Turin, tried another original approach to the mechanization of logic and published his design in a booklet of 1906 (Pastore 1906). Pastore's machine was a contrivance built with pulleys, differential gears and pendulums, arranged in three groups (for subjects, predicates and middle terms of a syllogism) connected by belts. If the syllogism was valid (true) the wheels rotate smoothly, if invalid (false) the wheels locked (Gardner 1958, pp. 114-116). Of course, all those machines were not intended for practical use or experimental demonstration, they were too clumsy, slow and could manage just a limited amount of propositions, but their educational value is still interesting.

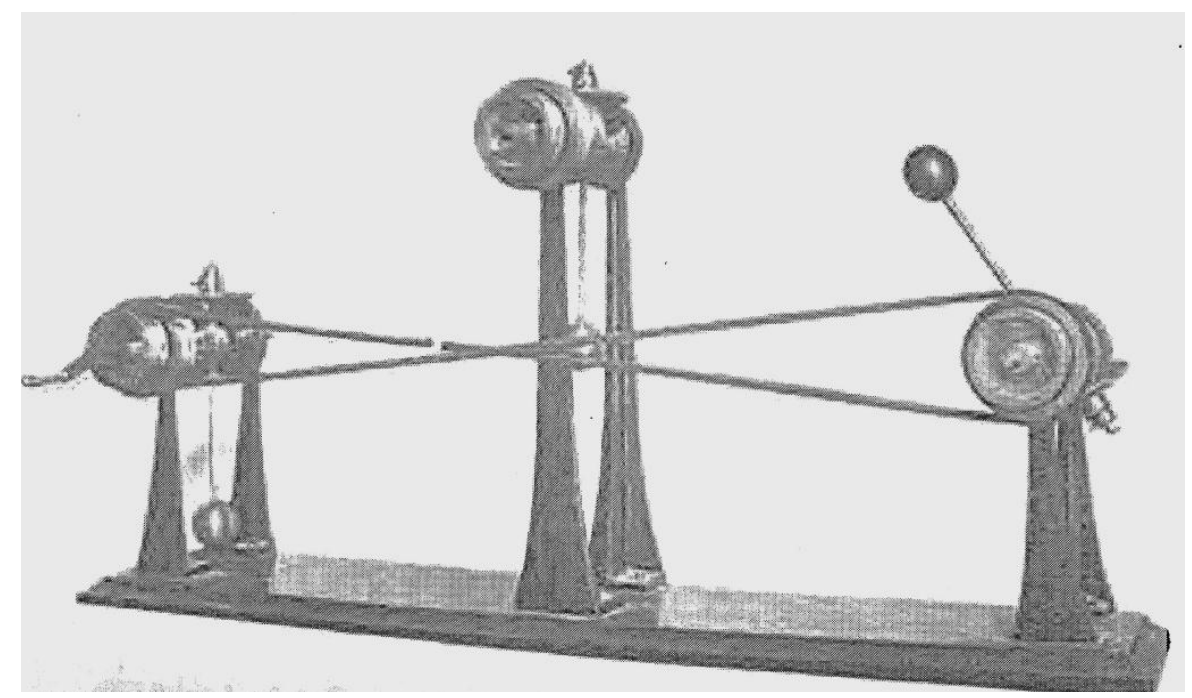

Fig. 11. Pastore's syllogistic calculator (Pastore 1906)

\subsection{Mechanical Analog Calculators}

In the first half of $20^{\text {th }}$ century the need of scientific and technical calculation abruptly increased, due to the development of nation-wide electric power networks, aviation, electronics, chemistry and nuclear physics. As no electronic digital computer was available yet, mathematical problems could be solved only with desktop fouroperation calculators or with analog computers like slide rules, planimeters and integrators. The mathematician Ernesto Pascal (1865-1940), professor of calculus at the University of Pavia until 1907, then at the University of Naples, devoted himself to 
the design of analog devices called 'intergraphs' . Differently from planimeters, intergraphs - invented by the Polish Bruno Abakanowicz (1880) - do not calculate the definite integral of a curve, but draw the integral function of a given curve and were used for the graphical-analytical solution of particular types of differential equations (e.g. Riccati's equation). Pascal's improved models, built by Roberto Marcolongo, were highly prized and reproduced for the use in mathematics departments of several universities. Other two Italian mathematicians, Lorenzo Poggi (1905 - 1978) from the University of Pisa, and Lamberto Cesari (1910 - 1990), from Istituto Nazionale per le Applicazioni del Calcolo of Rome (INAC - CNR), tried to build mechanical calculators for the solution of systems of linear equations. Poggi's, built with spinningwheel ribs, ${ }^{27}$ was just a crude prototype, although described in print (Poggi 1930). Cesari's design was patented. In 1939 Francesco Vercelli (1883 - 1952) published the description of a mechanical 'periodic analyzer' he invented (Vercelli 1939) to calculate periodicity of meteorological phenomena. Vercelli's design was built by the optic manufacture Salmoiraghi S.A. in Milan. It is now in the Museum of Physics of Turin University.

\subsection{The FERMIAC (1946)}

Between winter 1946 and summer 1947 ENIAC was dismantled and moved from Philadelphia's Moore School, PA, to Aberdeen Proving Ground, MD. (Burks 1981) Thus the first and sole high-speed electronic calculator was unavailable just when nuclear physicists had greatest need of it to keep the advantage they had in atom bomb design. The design required the modeling of neutrons collisions and scatterings, task that was carried out with the statistical 'Monte Carlo method' invented by John von Neumann and Stanislaw Ulam. This method, in turn, required repeated random sampling and subsequent calculation of particles trajectory, a rather tiresome and annoying operation, better performed by computers. In the absence of ENIAC, the Italian born physicist Enrico Fermi (1901-1954), leading scientist of the Manhattan Project, came out with a simple gadget to help (Metropolis 1987). With his colleague Percy King, Fermi designed and built this simple mechanism to draw random neutron paths in a lattice of fissile atoms, which was dubbed FERMIAC in assonance with first computers acronyms, like ENIAC, EDVAC, EDSAC. Although not properly a computing device, FERMIAC can be seen as the last mechanical contrivance in the just born electronic era.

\section{Conclusions}

After the flourishing of Italian mathematics and instrument making in the Renaissance, due to the early rediscovery and translation of ancient Greek, Hellenistic and Roman documents, and to the patronage granted to artisans and scholars by enlightened rulers, Italian science and technology underwent a long period of decline, the

\footnotetext{
${ }^{27}$ Actually, ribs of the tool used for holding skeins of yarn under tension to unravel them and to wrap yarn into balls.
} 
causes being too many and too intricate to be discussed here. Inventors and inventions were no longer prized by political and economic power until the late coming of industrial revolution (late $19^{\text {th }}$ century). As a matter of facts, the static and stratified society prevented the social promotion of gifted individuals, more easily obtainable in Great Britain, France and German countries. In fact, most of the mentioned inventors, as we have seen, were noblemen or held an academic position, and did not depend on their mechanical ingenuity for their bread and butter (perhaps with few exceptions, like Galileo and Torchi), thus in Italy inventor-entrepreneurs (Thomas Edison's style) were always poorly represented (with the exception of Guglielmo Marconi and few others). After 1900 Italian industry grew rapidly, but the time of independent inventors was over, replaced by companies' R\&D departments.

To conclude, certainly not all Italian inventors of computing instruments have been mentioned above and I apologize for all the names and inventions I have unintentionally forgotten; possibly twice as many are still to be discovered browsing through dusty documents, patents and reports scattered in the host of archives of universities, scientific societies and industrial companies. This paper is thus not meant to be a comprehensive and ultimate treatise on the topic, but rather a starting point to stimulate scholars to undertake a thoroughly study of the Italian history of technology, still a quite neglected subject in our country, putting together diverse competences of historians, scientists, engineers, sociologists and economists with a multidisciplinary approach.

\section{References}

Anastasio (1994) Anastasio, P.: Facini, Santo Bernardo. Dizionario Biografico Degli Italiani 44, Treccani (1994)

Andretta (2009) Andretta, E.: Bartolomeo Eustachi, il compasso e la cartografia del corpo umano. Quaderni Storici 44(1), 130 (2009)

Aquilecchia (1957) Aquilecchia, G. (ed.): G. BRUNO, Due dialoghi sconosciuti e due dialoghi noti. Edizioni di Storia e Letteratura, Rome (1957)

Austrian (1982) Austrian, G.D.: Herman Hollerith. Forgotten Giant of Information Processing. Columbia University Press, New York (1982)

Barnard (1869) Barnard, F.A.P.: Report on Machinery and Processes of the Industrial Arts and Apparatus of the Exact Sciences, pp. 637-638. D. van Nostrand, New York (1869)

Bedini (1995) Bedini, S.A.: The fate of the Medici-Lorraine Scientific Instruments. Journal of the History of Collections 7(2), 159-170 (1995)

Beniger (1986) Beniger, J.R.: The Control Revolution. Harvard University Press, Cambridge (1986)

Berzolari (1939) Berzolari, L.: Necrologio di Ernesto Pascal. Rend. Ist. Lombardo 3(12), 162170 (1939-1940)

Bianca (1982) Bianca, C.: Federico Commandino. In: Dizionario Biografico Degli Italiani, vol. 27, Ist. Dell'Enciclopedia Italiana, Roma (1982)

Boffito (1931) Boffito, G.: Il primo compasso proporzionale costruito da Fabrizio Mordente e la operatio cilindri di Paolo dell' Abbaco. Il Facsimile (6) (1931) 
Bonfanti (1988) Bonfanti, C.: Sulla macchina aritmetica di Poleni. In: Soppelsa, M.L. (ed.) Giovanni Poleni Idraulico, Matematico, Architetto, Filologo (1683-1761), Padua, pp. 163174 (1988)

Borchi (1997) Borchi, E., Macii, R.: Tito Gonnella, inventore nella Firenze dell'Ottocento. In: Borchi, E., Macii, R., Vetrano, F. (eds.) Strumenti di Fisica e Cultura Scientifica Nell'Ottocento in Italia, Florence, pp. 103-110 (1997)

Bromley (1990) Bromley, A.G.: Analog Computing Devices. In: Aspray, W. (ed.) Computing before Computers, pp. 159-199. Iowa State University Press (1990)

Buck (1999) Buck, G.H., Hunka, S.M.: W. Stanley Jevons, Allan Marquand and the Origins of Digital Computing. IEEE Annals of the History of Computing 21(4), 21-27 (1999)

Burks (1981) Burks, A.W., Burks, A.R.: The ENIAC: The First General-Purpose Electronic Computer. Annals of the History of Computing 3(4), 310-389 (1981)

Camerota (2000) Camerota, F.: Il compasso di Fabrizio Mordente: per la storia del compasso di proporzione, L. S. Olschki, Florence (2000)

Camerota (2003) Camerota, F.: Two new attributions: a refractive dial of Guidobaldo del Monte and the Roverino Compass of Fabrizio Mordente. Nuncius XVIII, 1 (2003)

Campbell-Kelly (1989) Campbell-Kelly, M.: ICL. A Business and Technical History. Clarendon Press (1989)

Campbell-Kelly (2003) Campbell-Kelly, M., Croarken, M., Flood, R., Robson, E.: The History of Mathematical Tables. From Sumer to Spreadsheets. Oxford University Press, Oxford (2003)

Care Care, C.: Illustrating the History of the Planimeter, http: / / empublic.dcs . warwick.ac.uk/projects/planimetercare2 004 /Docs/report.pdf (accessed March 14, 2012)

Carse (1982) Carse, G.A., Urquhart, J.: Planimeters. In: Horsburg, E.M. (ed.) Handbook of the Napier Tercentenary Celebrations, or Modern Instruments and Methods of Calculation, Bell, London (1914); Charles Babbage Institute Reprint Series for the History of Computing. Tomash Publishers, Los Angeles, pp. 190-206 (reprinted 1982)

Celli (2006) Celli, A.: Convegno sulla sommatrice automatica, Castelplanio (August 22, 2006), http: / / www. comune. castelplanio.an.it/Engine/RAServePG.aspx/P/ $2775160100 /$ M/2500160101 (accessed February 6, 2012)

Celli (2010) Celli, A.: Appunti per una storia dei Registratori di Cassa italiani. L'ufficio d'Epoca (48) (2010)

Cipolla (1987) Cipolla, M.: La moneta a Firenze nel cinquecento. Il Mulino, Bologna (1987)

Corridi (1859) Corridi, F.: Adunanza ordinaria del dì 16 gennaio 1859. Atti verbali della I. e R. Accademia Toscana d'Arti e Manifatture vii(7), 170-178 (1859)

Cortada (1993) Cortada, J.: Before the Computer. Princeton University Press (1993)

De Fouchy (1763) De Fouchy, J.P.G.: Eloge de Jean POLENI, Marquis du St. Empire, (né 1683 mort 1761). Histoire et Mémoires de l'Académie Royale des Sciences [part. Histoire] 1763, p. 151 (1763)

Drake (1988) Drake, S.: Galileo. Una biografia scientifica. Il Mulino, Bologna (1988)

Drake (1999) Drake, S.: Essays on Galileo and the History and Philosphy of Science, vol. 3. University of Toronto Press, Toronto (1999)

Favaro (1883) Favaro, A.: Galileo Galilei e lo Studio di Padova. Le Monnier, Florence, vol. I (1883)

Favaro (1907) Favaro, A.: Per la storia del compassi di proporzione. Atti del reale Istituto Vento di Scienze e Lettere 67, 723-739 (1907-1908)

Fellman (1983) Fellmann, R.: Römische Rechentafeln aus Bronze. Antike Welt 14, 36-40 (1983) 
Galilei (1606) Galilei, G.: Le operazioni del compasso geometrico et militare. Padova (1606), http://fermi.imss.fi.it/rd/bdv?/bdviewer/bid=300783\# (accessed January 14, 2012)

Gamba (1988) Gamba, E.: Matematici urbinati del Cinque-Seicento. In: Gamba, E., Montebelli, V. (eds.) Le Scienze in Urbino nel tardo Rinascimento, Quattroventi, Urbino (1988)

Gardner (1958) Gardner, M.: Logic Machines and Diagrams. University of Chicago Press (1958)

Gennari (1839) Gennari, G.: Elogio del March. Gio. Poleni, Padua (1839)

Geymonat (1970) Geymonat, L.: Galileo Galilei. In: Geymonat, L. (ed.) Storia del Pensiero Filosofico e Scientifico, Garzanti, vol. II (1970)

Gonnella (1825) Gonnella, T.: Teoria e descrizione d'una macchina colla quale si quadrano le superfici piane. Antologia, Florence, V, XVII(52) (1825)

Gonnella (1859) Gonnella, T.: Descrizione di due macchine aritmetiche per l'addizione immaginate e costrutte da Tito Gonnella, Florence, Tip. Calasanziana (1859)

Hénin (2009) Hénin, S.: Poleni. Museo della Scienza e della Tecnologia, Milan, http: / /www. museoscienza.org/approfondimenti/documenti/ macchina_poleni / default.asp (accessed February 4, 2012)

Hénin (2010a) Hénin, S.: Two Early Italian Key-driven Calculators. IEEE Annals of the History of Computing (1), 34-43 (2010)

Hénin (2010b) Hénin, S.: Buon compleanno Mr. Hollerith. Mondo Digitale (34), 47-57 (2010)

Hénin (2012) Hénin, S., Temporelli, M.: An Original Italian Dial Adder Rediscovered. IEEE Annals of the History of Computing 34(2) (2012)

Henrici (1894) Henrici, O.: Report on planimeters. Report of the Sixty-forth Meeting of the British Association for the Advancement of Science, pp. 496-523 (1894)

Horsburg (1914) Horsburg, E.M. (ed.): Napier Tercentenary Celebration. Handbook of the Exhibition of Napier relics and of Books, Instruments, and Devices for Facilitating Calculation. Royal Society of Edinburgh (1914)

Ifrah (2000) Ifrah, G.: The Universal History of Numbers. John Wiley \& Sons (2000)

Jacob (1911) Jacob, L.: Le Calcul Mécanique. O. Doin et Fils, Paris (1911)

La Fama (1840) Anon: Macchina aritmetica inventata ed eseguita da Luigi Torchi milanese. In: Fama, L.: Rassegna di Scienze, Lettere, Arti, Industria e Teatri, vol. 10 Gabinetto di scienze, arti ed industria, Milan (1836)

Leupold (1727) Leupold, J.: Theatrum Arithmetico-Geometricum. Das ist Schauplatz der Rechen und Mess-Kunst, Leipzig (1727)

Maas (2005) Maas, H.: William Stanley Jevons and the Making of Modern Economics. Cambridge University Press (2005)

Marguin (1994) Marguin, J.: Histoire des intruments et machines à calculer. Hermann, Paris (1994)

Martin (1989) Martin, C.: Notes sur l'abacus d'Aoste. Memorie dell'Accademia Italiana di Studi Filatelici e Numismatici IV(fasc.1), 59-62 (1989)

Martin (1925) Martin, E.: Die Rechenmaschinen und ihre Entwicklungsgeschichte. J. Pappenheim, Berlin (1925)

Menninger (1992) Menninger, K.: Number Words and Number Symbols. A Cultural History of Numbers. Dover Pubbl., New York (1992)

Merton (1973) Merton, R.K.: The Sociology of Science: Theoretical and Empirical Investigations. University of Chicago Press, Chicago (1973)

Metropolis (1987) Metropolis, N.: The Beginning of the Monte Carlo Method. Los Alamos Science, Special Issue, 125-130 (1987)

Miniati (2009) Miniati, M. (ed.): Firenze Scienza. Le collezioni, i luoghi, i personaggi dell'Ottocento, Firenze (2009) 
Morland (1673) Morland, S.: The Description and Use of Two Arithmetick Instruments, Together with a Short Treatise, Explaining and Demonstrating the Ordinary Operations of Arithmetick, London (1673)

Nagler (1960) Nagler, J.: Beschreibung der Rechenmaschine des Antonius Braun. In: Blätter für Technikgeschichte, Vienna, pp. 81-87 (1960)

Needham (1959) Needham, J., Wang, L.: Science and Civilization in China: Mathematics and the Sciences of the Heavens and the Earth. Cambridge University Press, Cambridge (1959)

Ochetto (2009) Ochetto, V.: Adriano Olivetti, Marsilio (2009)

Pascal (1914) Pascal, E.: I miei intergrafi per equazioni differenziali. Libreria Scientifica e Industriale, Napoli (1914)

Pastore (1906) Pastore, A.: Logica formale dedotta dalla considerazione di modelli meccanici: con 17 figure ed 8 tavole fuori testo, Turin, Fratelli Bocca (1906)

Pietra (1934) Pietra, G.: La prima classificatrice è stata ideata da un italiano. Barometro Economico Italiano, 463-467 (August 10, 1934)

Pignoria (1613) Pignoria, L.: De Servis, Amsterdam (1613)

Poleni (1709) Poleni, G.: Miscellanea. Hoc est 1. Dissertatio de barometris, \& thermometris, 2. Machinae aritmeticae, ejusque usus descriptio, 3. De sectionibus conicis parallelorum in horologiis solaribus tractatus. Venice, Aloysium Pavinum (1709)

Pullan (1968) Pullan, J.M.: The History of the Abacus. Hutchinson (1968)

Ratcliff (2007) Ratcliff, J.R.: Samuel Morland and his calculating machines c.1666: the early career of a courtier-inventor in Restoration London. Brit. J. Hist. Science 40(2), 159-179 (2007)

Righini (1980) Righini, G., Righini, M.L.: Nota su un calcolatore logaritmico di Bernardo Facini. Annali dell'Istituto e Museo di Storia Della Scienza di Firenze 5(1), 61-74 (1980)

Roegel (2008) Roegel, D.: An Early Key-Driven Adding Machine. IEEE Annals of the History of Computing 30(1), 59-65 (2008)

Salvetti (2002) Salvetti, A., Pacchioli, E. (eds.): Le macchine sapienti di Natale Capellaro. Associazione Archivo Storico Olivetti, Ivrea (2002)

Schärlig (2001) Schärlig, A.: Compter avec des cailloux. Presses Polytechniques et Universitaires Romandes, Lausanne (2001)

Schärlig (2003) Schärlig, A.: Compter avec des jetons. Presses Polytechniques Universitaires Romandes (2003)

Schärlig (2006) Schärlig, A.: Compter avec des doigts. Presses Polytechniques et Universitaires Romandes, Lausanne (2006)

Semplici (2001) Semplici, S.: Un'azienda e un'utopia. Adriano Olivetti 1945-1960, Il Mulino (2001)

Silmo (2008) Silmo, G.: M.D.C., Macchine da calcolo meccaniche, Olivetti e non solo; Natale Capellaro - Il genio della meccanica. Tecnologicamente Storie, Ivrea (2008)

Smith (1925) Smith, D.E.: History of Mathematics. Special Topics on Elementary Mathematics, vol. II. Ginn and Company (1925)

Soppelsa (1963) Soppelsa, M.L. (ed.): Giovanni Poleni (1683-1761), nel bicentenario della morte. Atti e memorie dell'Accademia patavina di scienze lettere ed arti, vol. 74(suppl.) (1963)

Soppelsa (1983) Soppelsa, M.L.: Giovanni Poleni idraulico, matematico, architetto, filologo (1683-1761): atti della Giornata di studi, Padua, Erredici (1988)

Soresini (1971) Soresini, F.: La storia del calcolo automatico, Roma, Confindustria, vol. I (1971) 
Soresini (1991) Soresini, F.: La macchina aritmetica di Giovanni Poleni e la sua ricostruzione. In: Atti Precongressuali del Convegno Internazionale Sulla Storia e Preistoria del Calcolo Automatico e dell'Informatica, Siena, Milan, AICA (1991)

Tancon (2005) Tancon, J.: Lo scienziato Tito Livio Burattini al servizio del Re di Polonia. Università di Trento (2005)

Targosz (1982) Targosz, K.: La cour çavant de Marie Louise de Gonzague, Krakow (1982)

Torchio (1999) Torchio, C.: L'ufficio d'Epoca, 14, 17, 20 (1999)

Turck (1972) Turck, J.A.V.: Origin of Modern Calculating Machines, New York (1972)

Vergara-Caffarelli (1992) Vergara Caffarelli, R.: Il Compasso Geometrico e Militare di Galilei, Testi, annotazioni e disputa negli scritti di. In: Galilei, G., Bernegger, M., Capra, B. (eds): Documenti e contributi di storia della scienza, ETS, Pisa (1992)

Vergara-Caffarelli (2006) Vergara-Caffarelli, R.: Il compasso geometrico militare. 2 - Studio del compasso galileiano di Pisa (2006),

http: //www.illaboratoriodigalileogalilei.it/galileo/2006\%20\%20 Studio\%20de1\%20 compasso\%20di\%20Pisa. PDF (accessed January 14, 2012)

Vollrath (1997) Vollrath, H.-J.: Eine alte italienische Addiermaschine im Holzkasten. Historische Bürowelt 49, 25-27 (1997)

Welser (1594) Welser, M.: Antiqua quae Augustae Vindelicarum extant Monumenta, Venice (1594)

Vercelli (1939) Vercelli, F.: Analizzatore meccanico delle curve oscillanti. Pontificia Academia Scientiarum, Commentationes 3(19), 659-692 (1939)

Williams (1990) Williams, M.R.: Early Calculation. In: Aspray, W., et al. (eds.) Computing Before Computers, Iowa State University Press (1990)

Williams (1997) Williams, M.R.: History of Computing Technology. IEEE Computer Society, Los Alamitos (1997) 